\title{
UJI BEDA PENGARUH ARUS KAS OPERASI DAN TINGKAT HUTANG TERHADAP PERSISTENSI LABA PERUSAHAAN FOOD AND BAVERAGE DI BEI DAN BURSA EFEK FILIPINA
}

\author{
Anida Zuhrotul Laili, Sugeng Hariadi ${ }^{2 *}$ \\ STIE Malangkuçeçwara \\ *2Corresponding author: hariadisg@yahoo.com
}

\begin{abstract}
This study aims to analyze and obtain empirical evidence of the difference in the influence of operating cash flow and debt levels on earnings persistence in 2017-2019. The dependent variable of this study is earnings persistence, while the independent variable of this study consists of operating cash flow and debt levels. The population of this study is the food and beverage subsector manufacturing companies in the Indonesia Stock Exchange and the Philippines Stock Exchange. The sample selection was done by using purposive sampling technique and resulted 81 samples. Thedata analysis technique in this research is using descriptive statistical analysis, classical assumption test and hypothesis testing. The classical assumption test includes normality test, multicollinearity test, heteroscedicity test and autocorrelation test. While the hypothesis test includes multiple linear regression analysis, partial test ( $t$ test) and difference test. The results of the hypothesis test show that the operating cash flow of companies onthe IDX has a significant effect on earnings persistence, while the level of debt has no significant effect on earnings persistence. Companies in the Philippine Stock Exchange show that operating cash flow and debt levels have no significant effect on earnings persistence. Operating cash flow and debt levels show a negative effect on earnings persistence. In addition, the different test showsthat there is a difference in the magnitude of the influence of operating cash flow and debt levels on earnings persistence in companies on the IDX and the Philippine Stock Exchange.
\end{abstract}

Keywords: Operating Cash Flow, Debt Level, Earning Persistence

Abstrak

Penelitian ini bertujuan untuk menganaisis dan memperoleh buktiempiris perbedaan besarnya pengaruh arus kas operasi dan tingkathutang terhadap persistensi laba pada tahun 2017-2019. Variabelterikat dari penelitian ini adalah presistensi laba, sedangkanvariabel bebas dari penelitian ini terdiri dari arus kas operasi dantigkat hutang. Populasi dari penelitian ini adalah perusahaanmanufaktur sub sektor food and beverage di Bursa Efek Indonesiadan Bursa Efek Filipina. Pemilihan sampel dilakukan dengan teknik purpossive sampling dan menghasilkan 81 sampel. Teknikanalisis data dalam penelitian ini menggunakan analisis statistikdeskriptif, uji asumsi klasik dan uji hipotesis. Uji asumsi klasikmeliput uji normalitas, uji multikolinearitas, uji heteroskedstisitas dan uji autokorelasi. Sedangkan uji hipotesis meliputi uji analisisregresi linear berganda, uji parsial (uji t) dan uji beda. Hasil dari ujihipotesis menunjukkan bahwa arus kas operasi pada perusahaan diBEI berpengaruh signifikan terhadap persistensi laba, sedangkantingkat hutang berpengaruh tidak signifikan terhadap persistensi laba. Pada perusahaan di Bursa Efek Filipina menunjukkan bahwaarus kas operasi dan tingkat hutang berpengaruh tidak signifikanterhadap persistensi laba. Arus kas operasi dan tingkat hutangmenunjukkan pengaruh negatif terhadap persistensi laba. Selainitu, pada uji beda menunjukkan bahwa terdapat perbedaanbesarnya pengaruh arus kas operasi dan tingkat hutang terhadappersistensi laba pada perusahaan di BEI dan Bursa Efek Filipina.

Kata Kunci: Arus Kas Operasi, Tingkat Hutang dan persistensilaba

\section{PENDAHULUAN}

Laporan keuangan merupakan salah satu sumber informasi keuangan yang sangat penting bagi perusahaan baik bagi pihak internal maupun pihak eksternal perusahaan. Didalam laporan keuangan terdapat informasi mengenai laba yang berperan sangat penting sebagai dasar pengambilan keputusan. Oleh karena itu perusahaan harus memperoleh laba yang berkualitas atau laba yang presisten untuk mempertahankan kelangsungan usahanya.

Suatu perusahaan harus memilliki laba yang presisten untuk kelancaraanaktifitas 
operasional perusahaan. Menurut Penman (2001) laba yang berkualitasadalah laba yang dapat mencerminkan keberlangsungan laba di masa depan, dandapat mempertahankan jumlah labanya, relevan dan reliabel. Dalam penelitian Romasari (2013) menyebutkan bahwa perusahaan yang mampu mempertahankan labanya dari tahun ke tahun lebih membuat para investor tertarik, karena menurut mereka perusahaan ini mampu menjaga kondisi perusahaan untuk tetap stabil. Dari pernyataan tersebut berarti bahwa semakin stabil peruvahan laba dari waktu ke waktu maka para investor akan semakin tertarik untuk berinvestasi.

Sebenarnya banyak faktor yang dapat mempengaruhi persistensi laba, akan tetapi pada penelitian ini faktor penentu presistensi laba menggunakan 2 variabel, yaitu arus kas operasi dan tingkat hutang. Laporan arus kas bisa diartikan sebagai catatan keuangan yang berisi tentang informasi mengenai keluar masuknya kas selama satu periode. Nilai yang terkandung dalam arus kas operasi pada suatu periode mencerminkan nilai laba dalam metode kas. Laporanarus kas operasi berisi segala kegiatan dan beban perusahaan secara langsung, dengan kata lain aktivitas ini berupa segala bentuk transaksi yang dapat mempengaruhi secara langsung terhadap kas dalam penentuan laba bersih. Olehkarena itu, arus kas operasi juga dapat berpengaruh terhadap persistensi laba, seperti yang telah disebutkan oleh (Septafita, 2016) bahwa arus kas operasi berpengaruh positif dan signifikan terhadap persistensi laba.

Kemampuan perusahaan dalam memperoleh laba tak lepas dari modal perusahaan yang seringkali didapatkan melalui hutang. Sebenarnya hutang akan menambah modal perusahaan, namun hutang juga menimbulkan konsekuensi perusahaan untuk harus selalu membayar bunga dan pokok pinjaman pada saat jatuh tempo tanpa memperhatikan kondisi keuangan perusahaan. Oleh karena itu hutang harus dimanfaatkan sebaik mungkin agar memperoleh laba yang maksimal. Tingkat hutang yang tinggi dari perusahaan akan menyebabkan perusahaan meningkatkan persistensi laba dengan tujuan untuk mempertahankankinerja perusahaan yang baik di mata auditor dan investor (Fanani, 2010). Dalam penelitian sebelumnya (Darmansyah, 2016) menyebutkan bahwa tingkat hutang berpengaruh signifikan terhadap persistensi laba. Namun Suwandika \& Astika (2013) menyatakan bahwa tingkat hutang tidak berpengaruh signifikan terhadappersistensi laba.

Di Indonesia masalah mengenai kredibilitas atau informasi laba sering terjadi sehingga menyebabkan turunnya kepercayaaan investor terhadap persistensi laba. Salah satu permasalahan tersebut terjadi pada PT Wilmar Cahaya Tbk (CEKA) yang tidak bisa menjamin laba yang presisten. Pada tahun2018 laba CEKA yang kurang memuaskan karena laba bersih perusahaan mengalami penurunan dibandingkan dengan tahun 2017. Perseroan dalam siaran persnya di Jakarta mengungkapkan bahwa laba bersih CEKA pada tahun 2018 turun 13,75\% year on year menjadi 92,65 miliar dari 107,42 miliar yang dibukukan pada 2017. Pada tahun 2017 laba CEKA juga tercatat mengalami penurunan 56,98\% dari tahun ke tahun. Semakin tinggi persistensi laba maka koefisien respon laba akan meningkat. Hal ini menunjukkan bahwa laba perusahaan presisten. Sebalikya, semakin rendah persistensi laba maka koefisien repon laba akan menurun. Hal ini menggambarkan bahwa labe perusahaan tidak cukup.(http://www.neraca.co.id/article/114465/penjualan-cpo-domestik-turun- laba-bersihwilmar-cahaya-anjlok-1375).

Penelitian mengenai persistensi laba sebenarya sudah banyak dilakukan sebelumnya. Namun hasil yang didapat dari beberapa penelitia tidak konsisten dan terdapat research gap 
yang signifikan didalamnya. Perbedaan penelitian inidengan penelitian sebelumnya yaitu penelitian ini membandingkan (komparasi) besarnya pengaruh arus kas operasi terhadap tingkat hutang pada perusahaan manufaktur sub sektor food and beverage yang terdaftar di bursa efek Indonesiadan Bursa Efek Filipina.

Berdasarkan latar belakang diatas, maka penelitian ini bertujuan untuk menganalisis dan memperoleh bukti empiris mengenai perbedaan besarnya pengaruh arus kas operasi dan tingkat hutang terhadap persistensi laba pada perusahaan manfaktur sub sektor food and beverage di Bursa Efek Indonesia danBursa Efek Filipina.

\section{KERANGKA TEORITIS DAN PENGEMBANGAN HIPOTESIS Persistensi Laba}

Presistensi laba merupakan salah satu komponen nilai prediktif laba dan unsur relevansi. Laba bisa dikatakan presisten ketika aliran kas dan laba akrual berpengaruh terhadap laba tahun depan dan perusahaan dapat mempertahankan jumlah labanya yang diperoleh saat ini sampai sampai masa yang akan datang (Barth \& Hutton, 2001). Sedangkan Penman \& Zhang (2002) mendefinisikan persistensi laba ssebagai revisi dalam laba akuntansi yang diharapkan dimasa mendatang yang disebabkan oleh inovasi laba tahun berjalan. Pada penelitian ini pengertian persistensi laba mengacu pada kinerja keseluruhan perusahaan yang tergambar dalam laba perusahaan. Pengertian ini menyatakan laba yang persistentinggi terefleksi pada laba yang berkesinambungan untuk suatu periode yang lama.

\section{Arus kas operasi}

Laporan arus kas adalah laporan keuangan yang melaporkan penerimaan kas, pengeluaran kas dan perubahan kas bersih hasil dari aktivitas operasi, invstasi, dan pendanaan suatu perusahaan selama satu periode akuntansi. Pada penelitianini memakai arus kas operasi dari aktivitas operasi. Arus kas operasi merupakanarus kas masuk dan kas keluar yang terkait langsung dengan pendapatan dan biaya yang dilaporkan daam laporan laba rugi. Seperti yang dikatakan oleh (Septafita, 2016) bahwa pada umumnya arus kas operasi berasal dari transaksi dan peristiwa lain yang mempengaruhi penetapan laba atau rugi bersih.

\section{Tingkat Hutang}

Tingkat hutang didefinisikan sebagai rasio total hutang dibandingkan total aset. Tingkat hutang berpengaruh terhadap persistensi laba karena setiap perusahaan memperoleh tambahan modal dengan berhutang untuk mengembangkan perusahaannya dan memaksimalkan laba yang dihasilkan. Hal tersebut dilakukanagar perusahaan bisa menjaga persistensi laba yang dihasikan. Hutang akan menambah modal perusahaan namun hutang juga menimbulkan konsekuensi perusahaan untuk harus selalu membayar bunga dan pokok hutang pada saat jatuh tempo tanpa memperhatikan kondisi keuangan perusahaan. Oleh karena itu, hutang harus digunakan sebaik mungkin untuk membiayai kegiatan perusahaan agar perusahaan dapat menjalankan usahanya dan menghasilkan laba yang maksimal. 


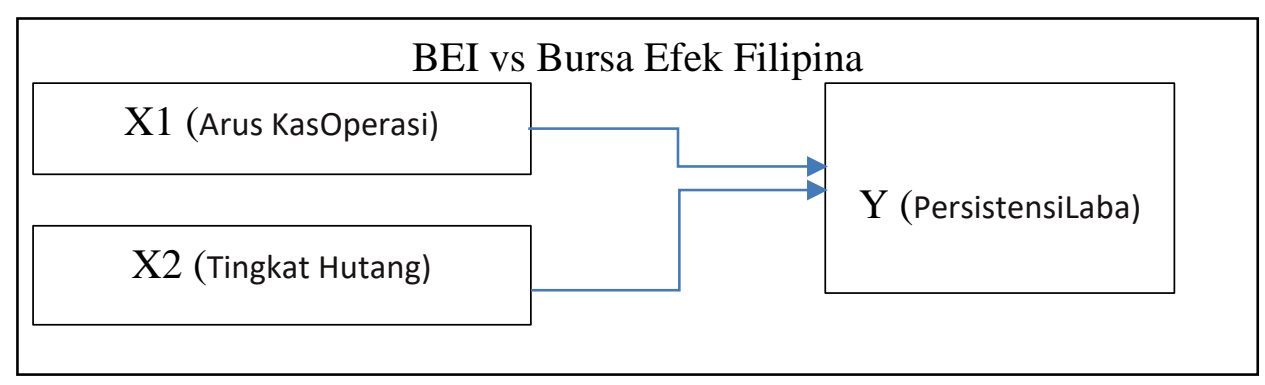

Gambar 1. Kerangka Konseptual

\section{METODE PENELITIAN}

Jenis penelitian ini adalah penelitian kuantitatif kausal. Dalam penelitianini penulis menggunakan penelitian uji beda (komparatif). Sumber data diperolehmelalui IDX Statistic (www.idx.co.id) dan The Philippine Stock Exchange (www.pse.com.ph). Data yang digunakan berupa laporan keuangan tahunan perusahaan manufaktur sub sektor food and beverage di Bursa Efek Indonesia dan Bursa Efek Filipina pada tahun 2017-2019.

Penelitian ini terdapat dua variabel yaitu variabel dependen $(\mathrm{Y})$ berupa persistensi laba dan variabel independen $(\mathrm{X})$ yang terdiri dari arus kas operasi $\left(\mathrm{X}_{1}\right)$ dan tingkat hutang $\left(\mathrm{X}_{2}\right)$. Variabel dan pengukuran dijelaskan dalam tebel berikut:

Tabel 1. Operasionalisasi Variabel dan Pengukuran

\begin{tabular}{|c|c|}
\hline Variabel & Pengukuran dan Skala \\
\hline \multirow[t]{2}{*}{$\begin{array}{l}\text { Persistensi } \\
\text { Laba }(Y)\end{array}$} & Laba sebelum pajakt-laba sebelum pajak $t-1$ \\
\hline & $\begin{array}{c}\text { Total aset } \\
\text { (Sumber : Persada dan Martani, 2010) }\end{array}$ \\
\hline \multicolumn{2}{|l|}{ Arus Kas } \\
\hline $\begin{array}{l}\text { Operasi } \\
\left(\mathrm{X}_{1}\right)\end{array}$ & $\begin{array}{c}\text { Total Aliran kas operasi } \\
\text { Total aset } \\
\text { (Sumber : Putri, 2017) }\end{array}$ \\
\hline $\begin{array}{l}\text { Tingkat } \\
\text { Hutang } \\
\left(\mathrm{X}_{2}\right)\end{array}$ & $\begin{array}{c}\frac{\text { Total Hutang }}{\text { Total Aset }} \\
\text { (Sumber : Fanani, 2010) }\end{array}$ \\
\hline
\end{tabular}

Populasi penelitian ini adalah perusahaan manufaktur sub sektor foodand beverage di BEI dan Bursa Efek Filipina pada tahun 2017-2019 sebanyak 59perusahaan. Sedangkakan pemilihan sampel dilakukan dengan metode purposive sampling dan menghasilkan sampel sebanyak 13 perusahaan di BEI dan 14 perusahaan di Bursa Efek Filipina selama 3 tahun, sehingga sampel dalam penelitian ini sebanyak 81 sampel.

Metode analisis data dilakukan dengan menggunakan program SPSS .Teknik analisis data menggunakan uji analisis deskriptif, uji asumsi klasik dan uji hipotesis. Uji asumsi klasik menggunakan uji normalitas, uji multikoinearitas, uji heteroskedastisitas dan uji autokorelasi. Sedangkan uji hipotesis menggunkan uji analisis regresi linear berganda, uji koefisien 
determinasi ( $\left.\mathrm{R}^{2}\right)$, uji parsial (ujit) dan uji beda.

\section{HASIL DAN PEMBAHASAN}

\section{Analisi Deskriptif}

Uji analisis deskriptif digunakan untuk mengetahui gambaran tentang data secaraumum yang terdiri dari nilai rata-rata, nimai minimal, nilai maksimal dan standardeviasi.

Tabel 2. Hasil Analisis Deskriptif Perusahaan di Bursa Efek Indonesia

\begin{tabular}{|c|c|c|c|c|c|}
\hline & $\mathrm{N}$ & Min. & Max. & $\begin{array}{c}\text { Mean (Rata- } \\
\text { rata) }\end{array}$ & Std. Deviation \\
\hline Arus Kas Operasi & 39 & 0,0001 & 0.531 & 0.144 & 0.1280 \\
\hline Tingkat Hutang & 39 & 0.1406 & 0.707 & 0.413 & 0.1707 \\
\hline Persistensi Laba & 39 & $-0,1024$ & 0.183 & 0.015 & 0.0454 \\
\hline Valid N (Listwise) & 39 & & & & \\
\hline
\end{tabular}

Sumber : Output SPSS 25 (2020)

Berdasarkan tabel 2 dapat diketahui bahwa nilai arus kas operasi minimum sebesar 0,0001 dimiliki oleh Tunas Baru Lampung Tbk. (TBLA) padatahun 2018. Selain itu TBLA juga memperoleh tingkat hutang maksimum pada tahun tersebut. Akan tetapi persistensi laba minimum justru diperoleh Wilmar Cahaya Tbk (CEKA) pada tahun 2017. Nilai arus kas operasi maksimum dan persistensi laba maksimum dimiliki oleh Multi Bintang Tbk. (MLBI) pada tahun2017. SEdangkan tingkat hutang minimum diperoleh Ultra Jaya Milk and Trading Company Tbk. (ULTJ) pada tahun 2018.

Tabel 3. Hasil Analisis Deskriptif Perusahaan di Bursa Efek Filipina

\begin{tabular}{lcccrr}
\hline & $\mathrm{N}$ & Min. & Max. & \multicolumn{2}{c}{$\begin{array}{c}\text { Mean (Rata- } \\
\text { rata) }\end{array}$} \\
\hline Arus Kas Operasi & 42 & $-0,089$ & 0.291 & 0.091 & 0.0662 \\
\hline Tingkat Hutang & 42 & 0,177 & 0.651 & 0.417 & 0.1361 \\
\hline Persistensi Laba & 42 & $-0,170$ & 0.150 & 0.056 & 0.0421 \\
\hline Valid N (Listwise) & 42 & & & & \\
\hline
\end{tabular}

Sumber: Output SPSS 25 (2020)

Dari tabel 3 dapat diketahui bahwa arus kas operasi minimum bernilai negatif yang berarti bahawa arus kas masuk lebih kecil daripada arus kas keluaryang dimiliki oleh Vitarich Corporation (VITA) dan tingkat hutang minimum pada tahun 2018. Sedangkan Macay Holdings, Inc. (MACAY) memiliki arus kasoperasi maksimum pada tahun 2017 dan memiliki tingkat hutang minimum padatahun 2019. Akan tetapi, persistensi laba minimum yang bernilai negatif juga dimiliki oleh MACAY pada tahun 2018. Hal ini dapat disimpulkan bahwa MACAY memperoleh laba yang tidak presisten pada tahun tersebut. Sedangangkan persistensi laba maksimum dimiliki oleh San Miguel Food and Beverage, Inc. (FB) pada tahun 2018 .

\section{Uji Asumsi Klasik}

Uji asumsi klasik digunakan untuk mengetahui terpenuhinya asumsi- asumsi klasik yang diperlukan dalam analisis regresi linear.

Uji Normalitas 
Tabel 4. Hasil Uji One Sample Kolmgorov-Smirnov Perusahaan di Bursa Efek Indonesia

\begin{tabular}{llr}
\hline & & $\begin{array}{c}\text { Unstandardized } \\
\text { Residual }\end{array}$ \\
\hline $\mathrm{N}$ & Mean & 33 \\
\hline Normal Parameters ${ }^{\mathrm{a}, \mathrm{b}}$ & Std. Deviation & .0000000 \\
\hline & Absolute & .01970285 \\
\hline Most Extreme Differences & Positive & .116 \\
\hline & Negative & .075 \\
\hline & & -.116 \\
\hline Test Statistic & & .116 \\
\hline Asymp. Sig. (2-tailed) & & .200 \\
\hline
\end{tabular}

Tabel 4. Hasil Uji One Sample Kolmogorov-Smirnov Perusahaan di Bursa Efek Filipina

\begin{tabular}{|c|c|c|}
\hline & & $\begin{array}{l}\text { Unstandardized } \\
\text { Residual }\end{array}$ \\
\hline $\mathrm{N}$ & & 26 \\
\hline \multirow[t]{2}{*}{ Normal Parameters ${ }^{\mathrm{a}, \mathrm{b}}$} & Mean & .0000000 \\
\hline & Std. Deviation & 1.62552459 \\
\hline \multirow[t]{3}{*}{ Most Extreme Differences } & Absolute & .151 \\
\hline & Positive & .073 \\
\hline & Negative & -.151 \\
\hline Test Statistic & & .151 \\
\hline Asymp. Sig. (2-tailed) & & .130 \\
\hline
\end{tabular}

Dari tabel 3 dan 4 dapat dilihat bahwa nilai Asymp. Sig. lebih dari 0,05 yakni, 0,2 dan 0,13 yang menunjukkan bahwa data tersebut terdistribusi normal. Hal tersebut juga dapat ditunjukkan dengan menggunakan uji normal p-plot dangrafik histogram.

Uji Multikolinearitas

Uji ini dilakukan untuk melihat ada atau tidaknya korelasi yang tinggi antara variabel variabel bebas dalam satu model regresi linear.

Tabel 5 Hasil Uji Multikolinearitas Bursa Efek Indonesia

\begin{tabular}{cccc}
\hline \multirow{2}{*}{ Model } & \multicolumn{2}{c}{ Collinearity } & \\
& Statistics & Keterangan \\
\cline { 2 - 4 } & Tolerance & VIF & \\
\hline Arus Kas Operasi & 0.497 & 2.011 & Tidak terjadi multikolinearitas \\
\hline Tingkat Hutang & 0.497 & 2.011 & Tidak terjadi multikolinearitas \\
\hline
\end{tabular}

Tabel 6 Hasil Uji Multikolinearitas Bursa Efek Filipina

\begin{tabular}{ccrl}
\hline \multirow{2}{*}{ Model } & \multicolumn{2}{c}{ Collinearity Statistics } & \\
\cline { 2 - 3 } & Tolerance & VIF & Keterangan \\
\hline Arus Kas Operasi & 0.981 & 1.019 & Tidak terjadi multikolinearitas \\
\hline Tingkat Hutang & 0.981 & 1.019 & Tidak terjadi multikolinearitas \\
\hline
\end{tabular}

Hasil Uji Multikolinearitas yang terdapat pada tabel 5 dan 6 menunjukkanbahwa model regresi yang dipakai untuk variabel-variabel independen penelitian tidak terdapat masalah 
multikolinearitas. Hal tersebut dikarenakan variabel independen menunjukkan nilai VIF yang kurang dari 10 dan nilai tolerance lebihdari 0,1 .

Uji Heteroskedastisistas

Uji ini bertujuan untuk mengetahui apakah dalam suatu persamaan regresi terjadi ketidaksamaan varians antara residual dari pengamatan satu dengan pengamatan yang lain.

Tabel 7. Hasil Uji Glejser Bursa Efek Indonesia

\begin{tabular}{clll}
\hline Model & $\mathrm{t}$ & Sig. & Keterangan \\
\hline (Constant) & 2.259 & 0.031 & \\
\hline Arus Kas Operasi & 0.150 & 0.882 & Tidak terjadi heteroskedastisitas \\
\hline Tingkat Hutang & -1.658 & 0.108 & Tidak terjadi heteroskedastisitas \\
\hline
\end{tabular}

Tabel 8.Hasil Uji Glejser Bursa Efek Filipina

\begin{tabular}{cccc} 
Model & $\mathbf{t}$ & Sig. & Keterangan \\
\hline (Constant) & 0.680 & 0.503 & \\
\hline Arus Kas Operasi & $-0,172$ & 0.865 & Tidak terjadi heteroskedastisitas \\
\hline Tingkat Hutang & $-0,523$ & 0.606 & Tidak terjadi heteroskedastisitas
\end{tabular}

Berdasarkan tabel diatas, dapat diketahui bahwa semua variabel bebas memiliki nilai sig. lebih besar dari 0,05 yang menunjukkan bahwa tidak terjadiheteroskedastisitas. Pada uji scatterplot juga menunjukkan bahwa tidak terjadimasalah heteroskedastisitas pada model yang diuji.

Uji Autokorelasi

Uji autokorelasi digunakan untuk menguji apakah model regresi linearada korelasi kesalahan pengganggu pada tahun periode $\mathrm{t}$ dengan kesalahan pengganggu pada periode $\mathrm{t}-1$ (tahun sebelumnya).

Tabel 9. Hasil Uji Durbin-Watson Bursa Efek Indonesia

\begin{tabular}{ccccc}
\hline Nilai DW & Nilai dL & Nilai dU & Nilai 4-dU & Kesimpulan \\
\hline 2.183 & 1.3212 & 1.5770 & 2,423 & Tidak terdapat autokorelasi \\
\hline
\end{tabular}

Tabel 10. Hasil Uji Durbin-Watson Bursa Efek Filipina

\begin{tabular}{crccc}
\hline Nilai DW & Nilai dL & Nilai dU & Nilai 4-dU & Kesimpulan \\
\hline 1.888 & 1.4073 & 1.6061 & 2,3939 & Tidak terdapat autokorelasi \\
\hline
\end{tabular}

Pada tabel 9 dapat dilihat bahwa niai Durbin-Watson sebsar 2,183. Dengan nilai signifikasi 5\%, jumlah unit analisis 33 (n) dan variabel independensebanyak $2(\mathrm{k}=2)$, didapat nilai dL sebesar 1,3212 dan dU sebesar 1,5770. Nilai DW berada dU dan 4-dU (2,423). Jadi, dapat disimpulkan bahwa tidak terdapat masalah autokorelasi pada model.

Begitu juga dengan tabel 10 dapat diketahui nilai Durbin-Watson sebesar 1,888. Dengan nilai signifikasi 5\%, jumlah unit analisis 42 (n) dan variabel independen sebanyak 2 $(\mathrm{k}=2)$, didapat nilai dL sebesar 1,4073 dan dU sebesar 1,6061. Nilai DW berada diantara dU dan 4-dU (2,3939). Jadi, dapat disimpulkanbahwa tidak terdapat autokorelasi pada model ini, sehingga model regresi layak dipakai untuk analisis selanjutnya. 


\section{Uji Hipotesis}

Dalam penelitian ini uji hipotesis digunakan untuk menguji pengaruh variabel independen, yakni arus kas operasi dan tingkat hutang terhadap variabel dependen yaitu persistensi laba.

\section{Analisis Regresi Linear Berganda}

Dalam penelitian ini uji hipotesis digunakan untuk menguji pengaruh variabel independen, yakni arus kas operasi dan tingkat hutang terhadap variabel dependen yaitu persistensi laba.

Tabel 11. Hasil Analisis Regresi Linear Berganda BEI

\begin{tabular}{lccc}
\hline \multirow{2}{*}{ Model } & \multicolumn{2}{c}{ Unstandardized Coefficients } & $\begin{array}{c}\text { Standardized } \\
\text { Coefficients }\end{array}$ \\
\cline { 2 - 4 } & $\mathrm{B}$ & Std. Error & Beta \\
\hline (Constant) & -0.014 & 0.019 & 0.495 \\
\hline Arus Kas Operasi & 0.146 & 0.070 & 0.174 \\
\hline Tingkat Hutang & 0.022 & 0.030 & \\
\hline
\end{tabular}

Berikut ini disajikan persamaan regresi untuk perusahaan di Bursa Efek Indonesia berdasarkan hasil analisis regresi linear berganda yang tersaji pada tabel 11:

$$
\mathrm{Y}=-0,014+0,146 \mathrm{X} 1+0,022 \mathrm{X} 2
$$

Hal tersebut dapat terlihat dalam penjelasan persamaan regresi linear berganda sebagai berikut:

1) $\alpha=-0,014$, Konstanta sebesar $-0,014$ artinya jika variabel arus kas operasi $\left(X_{1}\right)$ dan tingkat hutang $\left(\mathrm{X}_{2}\right)$ bernilai 0, maka persistensi laba $(\mathrm{Y})$ akan menurun sebesar 0,014. Hal ini dapat dilihat dari nilai koefisisen konstantanya yangbernilai negatif.

2) $\beta_{1}=0,146$, Koefisien regresi untuk variabel $X_{1}$ sebesar 0,146 akan mempengaruhi persistensi laba dengan asumsi variabel $X_{1}$ nilainya dinaikkan sebesar 1 satuan sedangkan variabel lainya tetap, maka persistensi laba akan mengalami perubahan atau akan meningkat sebesar 1,146.

3) $\beta_{2}=0,022$, Koefisien regresi untuk variabel $X_{2}$ sebesar 0,022 akan mempengaruhi persistensi laba dengan asumsi variabel $X_{2}$ nilainya dinaikkan sebesar 1 satuan sedangkan variabel lain tetap, maka persistensi laba akan mengalami perubahan atau akan meningkat sebesar 1,022.

Tabel 12. Hasil Analisis Regresi Linear Berganda Bursa Efek Filipina

\begin{tabular}{lccc}
\hline \multirow{2}{*}{ Model } & \multicolumn{2}{c}{ Unstandardized Coefficients } & $\begin{array}{c}\text { Standardized } \\
\text { Coefficients }\end{array}$ \\
\cline { 2 - 4 } & $\mathrm{B}$ & Std. Error & Beta \\
\hline (Constant) & -3.421 & 1.497 & 0.194 \\
\hline Arus Kas Operasi & 0.475 & 0.504 & 0.016 \\
\hline Tingkat Hutang & 0.093 & 1.182 &
\end{tabular}

Berikut ini disajikan persamaan regresi untuk perusahaan di Bursa Efek Indonesia berdasarkan hasil analisis regresi linear berganda yang tersaji pada tabel 12: 


$$
\mathrm{Y}=-3,421+0,475 \mathrm{X} 1+0,093 \mathrm{X} 2
$$

Hal tersebut dapat terlihat dalam penjelasan persamaan regresi linear berganda sebagai berikut.

1) $\alpha=-3,421$, Konstanta sebesar $-3,421$ artinya jika variabel arus kas operasi $\left(X_{1}\right)$ dan tingkat hutang $\left(\mathrm{X}_{2}\right)$ bernilai 0 , maka persistensi laba $(\mathrm{Y})$ akan menurun sebesar 3,421. Hal ini dapat dilihat dari koefisien konstantanya yang bernilai negatif.

2) $\beta_{1}=0,475$, Koefisien regresi untuk variabel $X_{1}$ sebesar 0,475 akan mempengaruhi persistensi laba dengan asumsi variabel $X_{1}$ nilainya dinaikkan sebesar 1 satuan sedangkan variabel lainnya bernilai teteap, maka persistensi laba akan mengalami perubahan atau akan meningkat sebesar 1,475.

3) $\beta_{2}=0,093$, Koefisien regresi untuk variabel $X_{2}$ sebesar 0,093 akan mempengaruhi persistensi laba dengan asumsi variabel $\mathrm{X}_{2}$ nilainya dinaikkan sebesar 1 satuan sedangkan variabel lainnya bernilai tetap, maka persistensi laba akan mengalami perubahan atau akan meningkat sebesar 1,093.

Jadi, dapat disimpulkan bahwa arus kas operasi dan tingkat hutang berpengaruh negatif terhadap persistensi laba baik pada perushaan di Bursa EfekIndonesia maupun di Bursa Efek Filipina

\section{Uji Parsial (Uji t)}

Uji t digunakan untuk mengetahui seberapa jauh pengaruh satu variabel $\mathrm{X}$ secara induvidu dalam menerangkan variasi variabel Y. Pengujian ini dilakukan dengan membandingkan nilai $t$ hitung dengan nilai $t$ tabel dengan syarat bila $t$ hitung $>t$ tabel atau probabilitas < tingkatsignifikansi $(\mathrm{Sig}<0,05)$, maka $\mathrm{H}_{\mathrm{a}}$ diterima dan $\mathrm{H}_{0}$ ditolak, yang artinya variabel independen berpengaruh signifikan terhadap variabel dependen secara parsial.

Dalam penelitian ini diketahui bahwa nilai t tabel dengan membandingakn nilai $\mathrm{df}=36$ untuk perusahaan di BEI dan $\mathrm{df}=39$ untuk perusahaan di bursa efek filipina dengan nilai sig $(0,05) / 2$.

Tabel 13 Hasil Uji t Bursa Efek Indonesia

\begin{tabular}{lllll}
\hline \multicolumn{1}{c}{ Model } & \multicolumn{1}{c}{$\mathrm{t}$} & \multicolumn{1}{c}{ Sign. } & \multicolumn{1}{c}{ Keterangan } \\
\hline Kontanta & $-0,771$ & 0,447 & \\
\hline Arus Kas Operasi $\left(\mathrm{X}_{1}\right)$ & 2,079 & 0,046 & Signifikan \\
\hline Tingkat Hutang $\left(\mathrm{X}_{2}\right)$ & 0,732 & 0,470 & Tidak signifikan \\
\hline
\end{tabular}

Tabel 14 Hasil Uji t Bursa Efek Filiina

\begin{tabular}{lllll}
\hline \multicolumn{1}{c}{ Model } & \multicolumn{1}{c}{$\mathrm{t}$} & & Sign. & Keterangan \\
\hline Kontanta & $-2,285$ & 0,032 & \\
\hline Arus Kas Operasi $\left(\mathrm{X}_{1}\right)$ & 0,942 & 0,356 & Tidak signifikan \\
\hline Tingkat Hutang $\left(\mathrm{X}_{2}\right)$ & 0,079 & 0,938 & Tidak signifikan \\
\hline
\end{tabular}

Berdasarkan hasil uji t untuk perusahaan di BEI pada tabel 13, maka dapatdisimpulkan bahwa:

1) Nilai signifikasi arus kas operasi (X1) terhadap persistensi laba (Y) adalah0,046 atau kurang dari 0,05 dan nilai thitung sebesar 2,079 atau lebih darit tabel (2,028). Hal tersebut menunjukkan arus kas operasi berpengaruh signifikan secara parsial terhadap persistensi laba.

2) Nilai signifikasi tingkat hutang $\left(\mathrm{X}_{2}\right)$ terhadap persistensi laba $(\mathrm{Y})$ adalah 0,356 atau lebih 
dari 0,05 da $n$ nilai t hitung sebesar 0,942 atau kurang darit tabel $(2,028)$. Hal tersebut menunjukkan tingkat hutang tidak berpengaruh signifikan secara parsial terhadap persistensi laba.

Sedangkan hasil uji t untuk perusahaan di bursa efek filipina pada tabel 15dapat disimpulkan sebagaiberikut:

1) Nilai signifikasi arus kas opeasi (X1) terhadap persistensi laba (Y) adalah 0,046 atau kurang dari 0,05 dan nilai t hitung sebesar 0,942 atau kurang dari t tabel (2,023). Hal tersebut menunjukkan bahwa arus kas operasi tidakberpengaruh signifikan secara parsial terhadap persistensi laba.

2) Nilai signifikasi tingkat hutang $\left(\mathrm{X}_{2}\right)$ terhadap persistensi laba $(\mathrm{Y})$ adalah 0,938 atau lebih dari 0,05 dan nilai t hitung sebesar 0,079 atau kurang darit tabel (2,023). Hal tersebut menunjukkan bahwa tingkat hutang tidak berpengaruh signifikan secara parsial terhadap persistensi laba.

\section{Uji Koefisien Determinasi $\left(\mathbf{R}^{\mathbf{2}}\right)$}

Uji koefisien determinasi digunakan untuk menguji seberapa besar pengaruh variabel bebas $(\mathrm{X})$ terhadap variabel terikat $(\mathrm{Y})$

Tabel 15. Hasil Uji Koefisien Determinasi $\left(\mathbf{R}^{2}\right)$ BEI

\begin{tabular}{ccccc}
\hline Model & $\mathrm{R}$ & R Square & $\begin{array}{c}\text { Adjusted R } \\
\text { Square }\end{array}$ & $\begin{array}{c}\text { Std. Error of } \\
\text { theEstimate }\end{array}$ \\
\hline 1 & 0.391 & 0.153 & 0.097 & 0.203490 \\
\hline
\end{tabular}

Tabel 16. Hasil Uji Koefisien Determinasi $\left(\mathbf{R}^{2}\right)$ Bursa Efek Filipina

\begin{tabular}{ccccc}
\hline Model & R & R Square & $\begin{array}{c}\text { Adjusted R } \\
\text { Square }\end{array}$ & $\begin{array}{c}\text { Std. Error of } \\
\text { theEstimate }\end{array}$ \\
\hline 1 & 0.197 & 0.039 & 0.045 & 1.69473 \\
\hline
\end{tabular}

Berdasarkan R Square pada tabel 16 dan 17 dapat dilihat bahwa sebesar $15,3 \%$ persistensi laba dipengaruhi oleh arus kas operasi dan tingkat hutang padaperusahaan BEI, dan sebesar 3,9\% pada perusahaan di Bursa Efek Filipina. Sedangakan sisanya dipengaruhi oleh variabel bebas lainnya yang tidak ada dalam penelitian ini.

\section{Uji Beda}

Teknik analisis yang digunakan untuk menguji hipotesis $\mathrm{H}_{1}$ dan $\mathrm{H}_{2}$ dengan menggunakan analisis regresi linear sederhana kemudian dilakukananalisis uji beda secara manual.

1) Terdapat Perbedaan Besarnya Pengaruh Aliran Kas Operasi terhadap Persistensi Laba antara Sub Sektor Food and Beverage di BEI dan Bursa Efek Filipina

Tabel 17. Uji Analisis Regresi Linear Sederhana

\begin{tabular}{llrrr}
\hline & \multicolumn{2}{l}{ Bursa Efek Indonesia } & \multicolumn{2}{c}{ Bursa Efek Filipina } \\
\hline Model & R & \multicolumn{2}{c}{ R Square } & \multicolumn{2}{c}{ R } & \multicolumn{2}{c}{ R Square } \\
\hline 1 & $0.371^{\mathrm{a}}$ & 0.138 & $0,197^{\mathrm{a}}$ & 0,039
\end{tabular}

Dari nilai R Square pada tabel 17 dapat diketahui bahwa pengaruh arus kas operasi 
terhadap persistensi laba adalah sebesar 13,8\% untuk perusahaan di Bursa Efek Indonesia dan 3,9\% untuk perusahaan di Bursa Efek Filipina, maka $\mathrm{H}_{1}$ diterima dan $\mathrm{H}_{0}$ ditolak karena terdapat perbedaan besarnya pengaruh arus kas operasi terhadap persistensi laba pada perusahaan di BEI dan Bursa Efek Filipina.

2) Terdapat Perbedaan Besarnya Pengaruh Tingkat Hutang terhadap Persistensi Laba antara Sub Sektor Food and Beverage di Bursa Efek Indonesia (BEI) dan Bursa Efek Filipina

\begin{tabular}{clcrl}
\multicolumn{4}{c}{ Tabel 18. Uji Analisis Regresi Linear Sederhana } \\
\hline & \multicolumn{2}{c}{ Bursa Efek Indonesia } & \multicolumn{2}{c}{ Bursa Efek Filipina } \\
\hline Model & $\mathrm{R}$ & R Square & $\mathrm{R}$ & \multicolumn{2}{c}{ R Square } \\
\hline 1 & $0.177^{\mathrm{a}}$ & 0.031 & $0,043^{\mathrm{a}}$ & 0,002
\end{tabular}

Dari nilai R Square pada tabel 18 dapat diketahui bahwa pengaruh arus kas operasi terhadap persistensi laba adalah sebesar 3,1\% untuk perusahaan di Bursa Efek Indonesia dan $0,2 \%$ untuk perusahaan di Bursa Efek Filipina, maka $\mathrm{H}_{2}$ diterima dan $\mathrm{H}_{0}$ ditolak karena terdapat perbedaan besarnya pengaruh arus kas operasi terhadap persistensi laba pada perusahaan di BEI dan Bursa Efek Filipina.

\section{Terdapat Perbedaan Besarnya Pengaruh Arus Kas Operasi terhadap Persistensi Laba antara Sub Sektor Food and Beverage di BEI dan Bursa Efek Filipina}

Hasil analisis dari uji beda menunjukkan bahwa terdapat perbedaan besarnya pengaruh arus kas operasi terhadap persistensi laba pada perusahaan di BEI sebesar 13,8\% dan sebesar 3,9\% untuk perusahaan di Bursa Efek Filipina, sehingga Hipotesis pertama diterima. Perbedan besarnya pengaruh antara keduasampel tersebut bisa terjadi karena kondisi ekonomi yang berbeda antara negaraindonesia dan Filipina atau kebijakan masing-masing perusahaan yang megharuskan untuk mengeluarkan kas untuk biaya operasional perusahaan yanglebih besar, misalnya seperti pembelian bahan baku dalam jumlah besar yang hanya tersedia pada waktuwaktu tertentu. Megendapnya piutang yang belum tertagih juga bisa menyebabkan kurangnya kas masuk, sehingga akan mempengaruhi persistensi laba

\section{Pembahasan}

Terdapat Perbedaan Besarnya Pengaruh Arus Kas Operasi terhadap Persistensi Laba antara Sub Sektor Food and Beverage di BEI dan Bursa Efek Filipina. Hasil analisis dari uji beda menunjukkan bahwa terdapat perbedaan besarnya pengaruh arus kas operasi terhadap persistensi laba pada perusahaan di BEI sebesar 13,8\% dan sebesar 3,9\% untuk perusahaan di Bursa Efek Filipina, sehingga Hipotesis pertama diterima. Perbedan besarnya pengaruh antara kedua sampel tersebut bisa terjadi karena kondisi ekonomi yang berbeda antara negara indonesia dan Filipina atau kebijakan masing-masing perusahaan yang megharuskan untuk mengeluarkan kas untuk biaya operasional perusahaan yanglebih besar, misalnya seperti pembelian bahan baku dalam jumlah besar yang hanya tersedia pada waktu-waktu tertentu. Megendapnya piutang yang belum tertagih juga bisa menyebabkan kurangnya kas masuk, sehingga akan mempengaruhi persistensi laba. 
Terdapat Perbedaan Besarnya Pengaruh Tingkat Hutang terhadap Persistensi Laba antara Sub Sektor Food and Beverage di BEI dan Bursa Efek Filipina. Hasil analisis dari uji beda menunjukkan bahwa terdapat perbedaan besarnya pengaruh tingkat hutang terhadap persistensi laba pada perusahaan di BEI sebesar 3,1\% sedangkan pada perusahaan di Bursa Efek Filipina yaitu sebesar $0,2 \%$, sehingga hipotesis kedua diterima. Perbedaan besarnya pengaruh tingkat hutang terhadap persistensi laba disebabkan oleh perbedaan kebijakan penggunan hutang pada setiap perusahaan di Bursa Efek Indonesia dan Bursa Efek Filipina.

\section{KESIMPULAN, KETERBATASAN DAN SARAN}

Berdasarkan pada data yang dikumpulkan beserta pengujian yang telah dilakukan mengenai perbedaan besarnya pengaruh antara arus kas operasi dan tingkat hutang terhadap persistensi laba pada perusahaan sub sektor food and beverage di Bursa Efek Indonesia dengan Bursa EfekFilipina, maka dapat disimpulkan bahwa, terdapat perbedaan besarnya pengaruh arus kas operasi terhadappersistensi laba pada perusahaan sub sektor food and beverage di Bursa Efek Indonesia dan Bursa Efek Filipina masing-masing sebesar 13,8\% dan $3,9 \%$. Selanjutnya juga terdapat perbedaan besarnya pengaruh tingkat hutang terhadap persistensi laba pada perusahaan sub sektor food and beverage di Bursa Efek Indonesia dan Bursa Efek Filipina masing-masing sebesar $3,1 \%$ dan 0,2\%.

\section{DAFTAR PUSTAKA}

Barth, M. E., \& Hutton, A. P. (2001). Financial Analysts and the Pricing of Accruals. SSRN Electronic Journal, 617.

Barus, A. ., \& Rica, V. (2014). Analisis Faktor-Faktor yang Mempengaruhi Persistensi Laba pada Perusahaan Manufaktur di Bursa Efek Indonesia. JWEM (Jurnal Wira Ekonomi Mikroskil), 4(2), 71-80.

Darmansyah. (2016). Pengaruh Aliran Kas, Perbedaan Antara Laba Akuntansi Dengan Laba Fiskal, Hutang Terhadap Persistensi Laba Pada Perusahaan Jasa Investasi. Jurnal Ilmiah WIDYA Ekonomika, 1(2), 1-7.

Fanani, Z. (2010). Analisis Faktor-Faktor Penentu Persistensi Laba. JurnalAkuntansi Dan Keuangan Indonesia, 7(1), 109-123.

Penman, S. H. (2001). On Comparing Cash Flow and Accrual Accounting Models for Use in Equity Valuation. SSRN Electronic Journal, 10027(212).

Penman, S. H., \& Zhang, X.-J. (2002). Accounting the Quality Stock of Conservatism , Earnings, Returns and Stock Return. The AccountingReview, 77(2), 237-264.

Putri, S. A. (2017). Aliran Kas Operasi, Book Tax Differences, Dan Tingkat Hutang Terhadap Persistensi Laba. Jurnal Riset Akuntansi Kontemporer, 9(1), 29-38. https://doi.org/10.23969/jrak.v9i1.365

Romasari, S. (2013). Pengaruh Persistensi Laba, Struktur Modal, Ukuran Perusahaan dan Alokasi Pajak Antar Periode Terhadap Kualitas Laba. Skripsi, 1(2), 1-21.

Septafita, N. (2016). Pengaruh Book Tax Difference, Arus Kas Operasi, TingkatHutang dan Ukuran Perusahaan terhadap Persistensi Laba. JOM Fekon, 3(2007), 1309-1323. 
Suwandika, I. M. A., \& Astika, I. B. . (2013). Pengaruh Perbedaan LabaAkuntansi, Laba Fiskal, Tingkat hutang pada Persistensi Laba. E-Jurnal Akuntansi Universitas Udayana, $1.5,196-214$. 